\title{
Municipal Bankruptcy: Pilot Experience from Czech Republic
}

\author{
Filip Hrůza ${ }^{1}$ \\ ${ }^{1}$ Department of Public Economics, Faculty of Economics and Administration, Masaryk University, Czech \\ Republic
}

Correspondence: Filip Hrůza, Faculty of Economics and Administration, Masaryk University, Lipova 41a, 602 00 Brno, Czech Republic. Tel: 420-724-330-084. E-mail: 99925@mail.muni.cz

\author{
Received: October 28, 2015 Accepted: December 16, 2015 Online Published: February 2, 2016 \\ doi:10.5539/res.v8n1p87 URL: http://dx.doi.org/10.5539/res.v8n1p87
}

\begin{abstract}
Local governments are important parts of public sector and they play significant role in daily life of residents. Their role is usually underestimated in comparison with central government tasks and responsibilities. Residents usually realize the real importance of municipal role when municipalities are in financial problems or even bankruptcy and for these reasons they have to restrict their services. This research paper focuses on the issue of financially distressed Czech municipalities and relevant financial areas or indicators in period prior financial problems of municipalities similar to a bankruptcy. This case study is specific due to the fact that this country misses bankruptcy legislation for municipalities and small total number of already existing cases of municipal bankruptcy due to limited time period of their higher autonomy after 1989. Thus the research sample of comparable cases is very limited and this paper serves as a pilot case study. The research for this paper is focused on the financial management of municipalities from the perspective of negative financial situations and the preceding phase to reveal and achieve certain preliminary findings and experience as a pilot lesson for financial management improvements and further exploration and research.
\end{abstract}

Keywords: municipality, bankruptcy, financial stress, signaling, experience, public policy, regulation

\section{Introduction}

One of the current topics of public finance is the increasing overall indebtedness of the public sector-including the municipal sector-in the shadow of central government. This is due to both the increasing proportion of indebted municipalities and an increase in risky management in certain municipalities. Local government debt is usually compared to central government still relatively very small but this issue is more about its micro- the macro- point of view and associated context to all local governments on individual basis. But even this fact the issue of local government debt with relevant associations in other field of studies is subject to continuous research (Benito \& Bastida, 2004; Horváthová et al., 2012; Gras et al., 2014; Hrůza 2014; Benito et al., 2015). In the twenty two years since the independent Czech Republic was formed, a group of municipalities have passed into states that are similar or close to the state of bankruptcy as a technical term or legal status. Such a status is usually regulated by federal legislation. In the Czech Republic, bankruptcy is addressed in, and regulated by, federal legislation only for companies and individuals. Even after more than twenty years of existence and the autonomous functioning of local government units in the Czech Republic, the issue of bankruptcy has not been adjusted for application to public sector entities such as municipalities, towns, and cities. The problem is that municipal bankruptcy is not regulated by law in the Czech Republic; therefore, a municipality does not have a legally established avenue for declaring bankruptcy. There is ongoing discussion about how to resolve the financial failures of municipalities, but no systematic solution has been adopted in the Czech Republic (Moderní obec, 2012). A municipality may enter a state or condition that is similar to bankruptcy, but there are no legislative tools or support that give municipalities the ability to be indicated as bankrupted. The advantage of bankruptcy status and associated legislation is that an economic subject with this status can use the benefits of such status, such as protection from creditors and a more comfortable process of financial recovery. The lack of a legally established definition for bankruptcy in terms of municipal finances could be solved using the generally accepted concept of bankruptcy and its form from other areas of the national economy.

The lack of legislation for municipal bankruptcy has certain negative implications. The recovery process is rendered problematic. Generally, bankruptcy as a specific process can help economic subjects in financial difficulties to get out of this situation and return to their actual function. But if this specific option does not 
technically exist in a particular segment (here, in the Czech municipalities), then their real function is associated with certain risks over the long term. If a negative financial situation occurs and could be permanent, a declaration of bankruptcy could help recover from this situation. If there is no bankruptcy legislation or relevant recovery tools, the path from this situation to recovery can be more difficult and complicated for the affected municipality.

The main objective of this paper is not to research municipal bankruptcy itself (expressed as the negative financial state of an economic entity), but to identify and describe the development and patterns of financial management of selected Czech municipalities on a pilot basis as this particular issue from perspective of public financial management is considered and researched at marginal rate. Due to the specific environment of the Czech Republic in this field, bankruptcy status is usually replaced in practice with receivership status or something similar. The expected outcome of this preliminary and pilot study is to bring first insights in this particular issue in the case of this country. This could then serve as a litmus test and preliminary findings for further and deeper research based also on other national and international experience and knowledge in this specific field.

\section{Conceptual Framework}

\subsection{Municipal Bankruptcy}

Generally the bankruptcy issue is very complex and multidimensional, municipal bankruptcy is no exception (Fudge, 2014; Scorsone \& Padovani, 2014). Bankruptcy in local governments has a lot of dimensions and aspects that should be taken into account and to be researched. At least there can be identified the following dimensions in which we can potentially research the bankruptcy issue: public policy, financial management, organizational theory etc. Thanks to its complexity, multidimensionality, importance or uniqueness there is a need to properly distinguish all of these and other associated aspects and research and explore this bankruptcy issue of local governments step by step. Therefore this particular research is aware of many diverse associated aspects potentially suitable for bankruptcy research but focuses primarily on the dimension of financial management. As this kind of specific research issue is at the very beginning in the Czech Republic this particular preliminary research focuses on positivistic description of the occurrence of bankruptcy phenomenon in case of Czech Republic from the view of financial management.

The risks and consequences of municipal bankruptcy can be identified thanks to the experiences and official records of relevant cases. Basic municipal functions are to maintain entrusted property and to provide services to citizens in a desired range or according to the municipality's own limited ability. The consequences of municipal bankruptcy usually occur as enforced changes in a municipality's expenditure management. There can be pressure to change the current municipal behavior or function. The negative impacts of municipal bankruptcy are reflected in, for example, the sale of municipal property and the restriction of municipal services. This and other related impacts go against the requirements and rights specified in the Czech Constitution and Municipal Act. The main negative consequences are that the federal government has to look for solutions restoring the affected self-government and it may also have to address the impact on government debt (Moderní obec, 2012). The government does not automatically have to take over the debts of an insolvent municipality. But other parallel effects, in the form of negative impacts on the local or regional economy, can occur when local government fails to meet its financial obligations (Honadle \& Lloyd-Jones, 1998).

One of the most important prerequisites for functioning municipalities is long-term financial sustainability, which has become one of key elements of municipal vitality and local government sustainability in general (Bolívar et al., 2014). In short, local governments cannot be liquidated out of business (ACIR, 1985). The financial sustainability of a municipality as a concept is closely tied to its purposes as defined by the relevant acts and the nature of its functioning. This paper examines the issue of financial sustainability in the Czech Republic. Recently, some municipalities have been heavily indebted, with fatal consequences for their functioning. The current practice is that an over-indebted or insolvent municipality can be directed by a relevant central ministry into federal receivership. Due to the complexity of this issue, it is desirable to seek a way to detect this state (bankruptcy) or ideally even to predict it (i.e. to recognize it through preventive indicators or financial behavior patterns). There are tendencies to strengthen monitoring and control mechanisms in the phase preceding what is essentially bankruptcy in a municipal economy by the Ministry of Finance, as evidenced by its establishment of a controlling and monitoring system of diverse financial and non-financial indicators, the System of Informative and Monitoring Indicators (in Czech, SIMU). The topic of municipal bankruptcy is a subject to continuous discussion throughout the world in practice and theory and from different perspectives (McConnell \& Picker 1993; Kloha et al., 2005; Mateos-Ronco \& Mas 2011; Civitillo, 2012; Fudge, 2014; 
Scorsone \& Padovani, 2014). But in the general overview of municipal bankruptcy literature there can be identified the prevalence of law literature than public administration, public finance or economics (Scorsone \& Padovani, 2014).

Municipalities and other economic entities manage their own property, revenues, and expenditures. Municipalities possess ownership rights to property and autonomy in the management of this property and in the management of revenues and expenditures due to secure conferred competences in a defined territory, and they provide selected goods and services. This research focuses on the issues of financially distressed Czech municipalities and relevant financial areas or indicators. This topic has not yet been well addressed. The research for this paper is focused on the financial management of municipalities from the perspective of negative financial situations and the preceding phase, not the actual bankruptcy process of restructuring and consolidating the economic entity, which is a separate issue. This paper aims to bring first insights and preliminary findings of particular bankruptcy issue in certain country as a pilot lesson for either policy makers or researchers because the associated general discussion lacks from our point of view this preliminary findings. However the preliminary findings achieved by this pilot research could be used for the international discussion about this particular issue because according to relative rarity of municipal bankruptcy it is highly desirable to discuss this issue more.

\subsection{The Negative Financial State of Municipalities in the Czech Republic}

Bankruptcy is a widely-used official term in the private sector. In the public sector, identifying relevant subjects situated in this or a similar state is problematic according to lack of relevant legislation, technical tools or proper and sound financial analytics methodology in case of bad financial management of municipalities. Their identification would be very beneficial, because it would enable the determination of what went wrong and whether this situation could be predicted and minimized in the future. A fundamental problem is the identification of appropriate subjects. The Ministry of Finance of the Czech Republic uses specific definition for those municipalities with higher level of risky management which means fulfillment of two conditions together-overall liquidity between $<0,1>$ and also the share of liabilities to total assets $>25 \%$. Their number and development during 2007-2011 is visible in following table. The main problem in using this analytical approach is lack of complexity. Even the ministry admits that municipalities can easily temporarily fulfill both conditions (especially in case of drawing from EU funds) without being really in difficult financial situation. Both indicators will be used in the set of finanacial-analytics indicators for the purpose of the measurements. There are no other proper overviews or statistics of the causes of the negative financial situations in the Czech Republic publicly available. The uniqueness of the Czech Republic case is stressed by relatively high municipal fragmentation according to historical development of local self-government (Bakoš et al., 2015).

Table 1. Development of Czech municipal sector (Ministry of Finance Czech Republic)

\begin{tabular}{lccccc}
\hline & 2007 & 2008 & 2009 & 2010 & 2011 \\
\hline Total number of municipalities & 6244 & 6244 & 6244 & 6245 & 6246 \\
Number of indebted municipalities & 3242 & 3229 & 3250 & 3112 & 3089 \\
Indebted municipalities (\%) & 51.9 & 51.7 & 52 & 49.8 & 49.5 \\
$\begin{array}{l}\text { Number of municipalities with higher level of risky } \\
\text { management* }\end{array}$ & n.a. & 26 & 44 & 62 & 84 \\
$\begin{array}{l}\text { Municipalities with higher level of risky } \\
\text { management* (\%) }\end{array}$ & n.a. & 0.4 & 0.7 & 1.0 & 1.3 \\
\hline
\end{tabular}

\subsection{Negative Financial State of Municipalities}

In his research, Hossari (2007) posed the question of when an economic entity is generally considered to be in a state of collapse. The variety of definitions of this state illustrates the diversity of signs and symptoms associated with this condition. Hossari highlighted the complexity of the perception of this special technical term from a financial perspective due to the difficulty of determining the point of collapse from which it is impossible to return to a good financial condition and a negative state is inevitable; he recommended legal interpretation.

There are different ways to define a negative state or financial emergency for a public sector entity. The following terms could be used to describe the negative financial state of a municipality (ACIR, 1985; Kloha et al., 2005; Jones \& Walker, 2007): 
- Bankruptcy;

- Default, General Obligation Bonds;

- Default, General Obligation Notes;

- Default, Government-Purpose Revenue Bonds or Notes;

- Default, Private-Purpose Revenue Bonds or Notes;

- Failure to Meet Other Obligations and State Declared Emergencies;

- Fiscal Crisis;

- Fiscal Distress;

- Financial Crisis.

All these terms express a negative financial condition of a municipality. A financial condition is, in a broader sense, described as "the financial ability of a local government to fulfill its obligations (short-term obligations, long-term obligations, operational obligations, and obligations to provide services to the public), to anticipate unexpected events, and to execute financial rights efficiently and effectively" (Groves et al., 1981; Wang et al., 2007; Rivenbark et al., 2009, 2010; Ritonga et al., 2012).

Ritonga et al. (2012) defines the ability to meet financial obligations as having the following features:

- The ability to meet short-term and long-term obligations (short-term and long-term solvency);

- The ability to cover its operations (budgetary solvency);

- The ability to provide services at the level and quality required and desired by its people (service-level solvency).

Ritonga et al. (2012) deal with short-term solvency in 12-month periods instead of 30-60 day periods. This approach is also used in this study because the primary data sources are mainly from a time period before the public sector accounting reform was implemented.

It is interesting that different authors use different approaches and different instruments and indicators. This phenomenon has its own logic, as towns and cities in different countries are subject to varying financial management conditions. For example, tax legislation has a major influence on the design and structure of municipal budgets and varies among countries. This is a completely different view from the variety among private companies.

\subsection{Factors Affecting the Financial Situations of Municipalities}

Identifying the potential factors affecting financial management is important in defining the areas that need to be addressed when analyzing the examined entities. New perspectives can be uncovered even during the examination. Relevant risk factors that can lead to bankruptcy include (Civitillo, 2012):

- Mismanagement (e.g. Deficits);

- Overly ambitious management goals;

- Short-term management policies;

- Mismanagement of cash flow;

- Excessive debt exposure;

- Inefficient management control system;

- Inability to promptly identify potential causes of damage and/or inability to act promptly to remove them;

- Uncontrolled increase of expenditure;

- Growing deficit (without making investments);

- Continuous increase of certain local taxes;

- Discontinuity in management;

- Lack of business management tools to support management;

- Negative events involving the market.

For the purposes of this paper, only financial indicators will be taken into consideration within the chosen 
analytical approach.

\section{Research Design}

As the supporting dimension that has been chosen for this research was selected public financial management. The reason is that financial management is the primary dimension of an organization in terms of financial condition and functioning. There are other relevant dimensions, internal and external factors, influencing the existence of certain entity but in pilot research and to achieve first preliminary findings there have been chosen the basic measurements associated with the financial condition for the purpose of the particular analysis. For the primary analysis of this particular issue it is suitable first to use positive and descriptive financial statistics to identify the phenomena, its form, shape and progress and describe it. Then it is possible to follow up on those preliminary findings and either continue in this type of research to enlarge the research sample and more robust data or start with exploratory research and deeper analysis. Thus there have been chosen the following methodology and methods. Core argument for the chosen specific methods and methodology is already mentioned relative rarity of municipal bankruptcy and its local uniqueness according specific national legislation and policy, locally relevant, organizational and administration specifics etc. Therefore typical large $\mathrm{n}$ studies are unlikely to be useful and due to data limitations are case studies more common (Scorsone \& Padovani, 2014).

\subsection{Used Research Methods and Methodology}

The main methodology of this research is modified data triangulation using both quantitative and qualitative approaches. Quantitative research is used for the primary analysis of selected relevant financial data and combined financial indicators. An important prerequisite for addressing this research problem is a suitable approach to sample analysis. The historically significant financial analysis tools were identified on the basis of a study of the relevant literature and related studies use the following main approaches, which are based on the methodological process of theoretical research of economic subjects in the private sector (mostly in the U.S.):

- Identification of Significant Aspects of a Sample of Failed Economic Subjects (Smith \& Winakor, 1930);

- Identification of Differences between Successful and Unsuccessful Economic Subjects (Fitzpatrick, 1932);

- Identification of Aspects of Successfully Performing Economic Subjects (Merwin, 1940).

For the purposes of this research, the approach of identifying significant aspects of a sample of economic subjects with specific financial problems was chosen, in this case consisting of Czech municipalities that went into a state similar or close to bankruptcy. The reason why this approach was chosen is that selecting successful subjects in this specific sector is a complex issue and outside the framework of this paper. The aim of this part of the research is to identify the financial aspects and symptoms associated with this condition (Evans \& Patton, 1987). The qualitative research consisted of analyzing the operational management of the sample municipalities in the reporting period in order to identify the significant steps leading to the deterioration of the municipal financial situation.

\subsection{Sample Identification}

For the purposes of this research of a widely debated but little explored issue, there were selected three municipalities that could be considered to have experienced a condition that was similar or close to bankruptcy. There are several possible approaches to addressing and solving related issues. One possible approach to understanding municipal bankruptcy is to find how a municipality reaches this state by looking at the relevant conditions preceding it. Since there is no general consensus on the use of financial indicators for assessing the financial situation of municipalities, and there are a number of approaches and solutions for analyzing municipalities from this perspective, a basic financial analysis approach in the form of selected indicators (quantitative research) was chosen combined with a description of the managerial behavior of a given municipality (qualitative research). The quantitative part of the research is based on the financial documents of the relevant municipalities (balance sheets, income statements, and budgets). The qualitative part of the research is based on an analysis of the publicly available documents, materials, and sources on the management of the municipality, and is enriched by a comparison with the research outcomes of previous similar studies.

There are some limitations associated with this research approach that need to be taken into account:

- Identification of Suitable Entities for a Research Sample;

- The Absence of the Institute of Bankruptcy for Municipalities;

- Accounting Reform in the Public Sector (A 2010 Change In The Statements And Policies) Transparent 
Managerial Control and Reporting in Municipalities Was not Available in Every Case;

- More Difficult Work with Data (Need to Manually Download Selected Data from Official Ministry Databases).

Due to its limitations, this paper is of a pilot nature and includes only selected municipalities from this one country of different sizes in financial difficulties shown in the table 2.

Table 2. Sample of municipalities from Czech Republic

\begin{tabular}{cc}
\hline Municipality & Population \\
\hline A & 4535 \\
B & 373 \\
C & 141 \\
\hline
\end{tabular}

The data from 2007 to 2012 were chosen for analysis due to the availability of relevant data from the Ministry of Finance database and the willingness of the selected municipalities to provide relevant information and data, as well as due to the data continuity.

Municipalities and other economic entities manage their own property and, in the long term, specific revenues and expenditures. Municipalities possess ownership rights to property and autonomy in the management of this property and in the management of revenues and expenditures due to secure conferred competences in a defined territory, and they provide selected goods and services. One of the most important prerequisites for the functioning of municipalities is long-term financial sustainability. The financial sustainability of a municipality as a concept is closely tied to the municipality's purpose, as defined in the amended Municipal Act in the Czech Republic concerning the existence and functioning of Czech municipalities (Czech Act No. 128/2000 Sb., On Municipalities). Relevant specific items related to the financial management of municipalities that differ from economic subjects in the private sector include revenues shared with the central government, specific revenues such as fees, performance of certain non-profit operations and activities, specific decision-making and control mechanisms, and organizational structure. Their processes of financial management are bound by certain common principles. Municipalities can, to some extent, change and influence some aspects of management. Their specific limitations can have a significant effect on their economic management; these conditions make municipal financial management more complex and demanding.

\subsection{Research Perspectives}

There some basic research approaches to studying the negative financial state of economic entities. A condition very similar to bankruptcy is associated with certain specific characteristics. Some research approaches focus on the prediction of such a state (Coe, 2008) and seek an answer within a certain prior time period, revealing some common symptoms. In terms of municipalities, all perspectives are important. The possibility of the definitive closure of a bankrupted economic entity, which is an option in the private sector, is undesirable in the municipal sector, because it is inconsistent with the requirement for the unlimited existence of the municipalities due to their specific and varied purpose in the economy, such as the provision of essential goods and services (Civitillo, 2012). The exception is the amalgamation of municipalities.

\section{Data Analysis and Findings-Results}

\subsection{Pilot Research of Selected Municipalities}

The aim of the research is to identify the financial conditions of Czech municipalities going into bankruptcy or a state very similar to bankruptcy in some way, to identify and describe their financial behavioral patterns in the period prior to the occurrence of the negative financial situation, and to find the characteristics and symptoms associated with this condition (Evans \& Patton 1987). Among the expected outcomes of this research paper is a positive description of the financial behavior of financially distressed municipalities in the period before the occurrence of such conditions. An anticipated secondary outcome is the identification of appropriate and specific narrow areas and indicators in the financial dimension of municipal management that will enable predicting negative situations in the period before they occur.

\subsubsection{The Causes of the Negative Situation (General Qualitative Approach)}

A number of financial management events and prior processes may lead to the occurrence of a negative situation 
in a municipality (Civitillo 2012). This part of the research presents brief descriptions of the significant management decisions of the six selected municipalities that led to their deteriorating financial situation. None of them managed the deficits that caused their significant negative financial situation and thus they were eventually forced under pressure of execution to give up the majority or some part of their property. Such behavior is poor financial management, because the time constraints increase short-term liquidity in order to meet short-term liabilities, leading to potential losses rather than the potential revenues that would result under ideal municipal property sale conditions. With the absence of the possibility to declare bankruptcy of a municipality as well as in the USA in the form of entry into Chapter 9 (US Courts 2013) and protection from creditors (banks, investors) there are limited ways how to tackle bigger financial problems. Following solutions are usually used:

- Involuntary Sale of Property and Settlement of Obligations;

- Takeover or Guarantee of Debts by Higher Territorial-Administrative Unit (County, State);

- Receivership Designated by the State.

First possibility is not a matter of economy but in some cases is used. Second solution is not very concerned because of moral hazard problem. Last, third, solution is also sometimes used when the financial situation is very bad and inevitable.

The municipality A sold the land for private housing construction; it was also involved in the construction of related networks. The municipality should have had some share of the income from the resale of these modified parcels, but it did not get anything. The municipality therefore ended in execution and the municipal property was blocked by executors in 2009 .

The municipality B got into a negative situation where it was unable to repay its accumulated debt. For this reason, it was forced to request large grant for debt relief. The supervising region (county) partially granted the money. The municipality got into this situation because of an ambitious housing project connected with sewerage construction. The inevitable and involuntary execution of municipal property was initiated in 2010.

The municipality $\mathrm{C}$ got into a negative situation because of plans for renovating a spa. It purchased the land for the project and expensive boreholes and licenses. But relevant environmental protection authorities ultimately did not allow build a bottling plant in this protected area. The unhedged position of the municipality within this project meant a huge debt, exceeding the municipal budget several times over. The municipality dealt with the debt by selling off almost all its property and by restricting provided public services. The execution process started between 2009 and 2010.

\subsubsection{The Causes of the Negative Situation (Financial Analysis Approach)}

This perspective of municipal bankruptcy issue from the view of financial analysis focuses on selection of suitable indicators to be used for the preliminary analysis of selected sample. As there can be nowadays indetified many different methods and tools for such analysis only those which are suitable to be used for this particular case were taken into consideration. Therefore it should meet certain requirement as financial nature of indicator and compatibility to Czech Republic cases (especially to their annual financial reports-relevant items).

When choosing relevant and suitable indicators for preliminary descriptive analysis there have been taken into consideration Brown (1993) or Maher and Nollenberger (2009) using financial indicators such as total general fund cash and investments / total general fund liabilities; total general fund liabilities / total general fund revenues; total revenues / total expenditures; general fund sources from other funds / total general fund sources; unreserved general fund balance / total general fund revenues; operating surplus or deficit / net operating revenue.

The financial trend monitoring system from ICMA can not be forgotten and due to its complexity and quantity of suggested indicators only some of them are briefly mentioned (the reason is also that this model is considered as suitable for operating management of a municipality thus not all indicators are intended to prevent bankruptcy or distress as predictors): intergovernmental revenues / operating revenues and transfers; fixed costs / operating expenditures and transfers; general fund unreserved fund balance / operating revenues and transfers; current assets / current liabilities; net operating revenues / total debt service etc.

Based on a study by Ngwenya (2010), some of the mentioned indicators will be used for a financial analysis approach. The analysis of financial management will be further complemented by other indicators. The reason for selecting these indicators is their applicability to the Czech municipal financial management accounting data available for this study. 
Table 3. Selected financial analysis indicators

\begin{tabular}{ll}
\hline Indicator name & Formula \\
\hline Acid-Test Ratio & $\begin{array}{l}\text { (current assets - inventory) / current } \\
\text { liabilities } \\
\text { total liabilities / total assets }\end{array}$ \\
$\begin{array}{l}\text { Debt to Asset Ratio (Leverage) } \\
\text { Unrestricted Net Assets to Expenses Ratio (Financial Position) }\end{array}$ & $\begin{array}{l}\text { unrestricted net assets / expenses } \\
\text { Annual Percentage Change in Net Assets to Total Net Assets }\end{array}$ \\
$\begin{array}{l}\text { Ratio (Financial Performance) } \\
\text { Level of Financial Autonomy }\end{array}$ & own equity / foreign equity \\
Financial Utilization of Equity & simple cash flow / own equity \\
Credit Worthiness of Cash Flow & foreign equity / simple cash flow \\
Annual Budget Balance & balance (+/-) \\
Annual Percentage Changes of Total Assets & annual change of total assets \\
Annual Percentage Changes of Short-Term Liabilities & annual change of short-term liabilities \\
\hline
\end{tabular}

Indicators other than those of a quantitative and financial nature were not chosen, as the quantitative part concerns analyzing the financial patterns and behavior of selected municipalities. The financial analysis indicators in the table 3 were chosen.

The current ratio is not examined, because the units under observation did not significantly differ in development and size from the quick ratio. Leverage can be also interpreted as inverse ratio of the self-financing coefficient.

From the table 4 there can be seen there is no clear trend for a quick ratio within the examined time period. The level of liquidity expressed by this indicator in the years immediately before the occurrence of the negative financial situation was about $10-20 \%$, mostly in the Czech municipalities. One or two years before the occurrence of the negative financial situation, the indicator was below $40 \%$ in four out of the six cases. In the period before the negative situation, there was no clear trend in this indicator that could signal or predict any risk. It is interesting that all six municipalities reached significant drops in liquidity within the observed period (2007-2012).

Table 4. Acid-test ratio

\begin{tabular}{ccccccc}
\hline Municipality & 2007 & 2008 & 2009 & 2010 & 2011 & 2012 \\
\hline A & $76 \%$ & $17 \%$ & $11 \%$ & $51 \%$ & $190 \%$ & $177 \%$ \\
B & $26 \%$ & $10 \%$ & $13 \%$ & $126 \%$ & $194 \%$ & $341 \%$ \\
C & $19 \%$ & $25 \%$ & $34 \%$ & $28 \%$ & $17 \%$ & $31 \%$ \\
\hline
\end{tabular}

Liquidity is a valuable aspect of financial management research and an important feature of economic entities (Hrůza, 2013). It should be more properly studied and analyzed from different perspectives; this public sector issue is not mainstream, but it is important. For further research, it would be appropriate to focus attention on key moments in various relationships, such as between liquidity and the involvement of foreign funds.

The leverage indicator achieves its maximum values shortly before the negative financial situation occurs, and then within it in some cases. The measurements in individual cases are also valuable, because the larger the entity, the lower the maximum value of the indicator reached before the occurrence of the negative financial situation. Another interesting fact is that some of the observed entities were forced by external pressure into drastic managerial actions, mostly the involuntary sale of municipal property, even at values lower than $30 \%$ of the leverage ratio. It would be beneficial to examine this issue in the context of government regulation of municipal economies and determine whether the regulations are appropriately set. 
Table 5. Leverage

\begin{tabular}{ccccccc}
\hline Municipality & 2007 & 2008 & 2009 & 2010 & 2011 & 2012 \\
\hline A & $20 \%$ & $26 \%$ & $27 \%$ & $21 \%$ & $23 \%$ & $22 \%$ \\
B & $30 \%$ & $27 \%$ & $24 \%$ & $22 \%$ & $22 \%$ & $20 \%$ \\
C & $66 \%$ & $52 \%$ & $64 \%$ & $294 \%$ & $595 \%$ & $518 \%$ \\
\hline
\end{tabular}

The indicator of the financial position expressing coverage of budget expenditures by unrestricted net assets shows that the financial situation was volatile due to the budget during the examined period, but it is not certain that it was critical. However, it reflects the relationship between the budget and municipal property.

Table 6. Financial position

\begin{tabular}{ccccccc}
\hline Municipality & 2007 & 2008 & 2009 & 2010 & 2011 & 2012 \\
\hline A & 6.18 & 3.74 & 5.77 & 7.39 & 5.09 & 6.41 \\
B & 4.60 & 14.11 & 18.64 & 19.52 & 15.21 & 18.41 \\
C & 9.55 & 16.32 & 1.23 & -28.70 & -7.41 & -1805.67 \\
\hline
\end{tabular}

It seems in this specific case that this modification of municipal budget annual indicator does not distinctly signal an adverse financial situation of observed municipalities. The pre-crisis period indicates no significant budgetary restrictions in terms of total expenditure. In conjunction with other potential research, it would be worthwhile to confirm this assertion by analyzing the structure of expenditure within the observed period, because the situation could hypothetically be caused by a change in the structure of expenditures.

In most of the observed cases, poor financial performance is evident over a longer period before the occurrence of the negative financial situation. In the post-critical period, it is necessary to also take into account the influence of accounting reform and its procedures in the public sector. From table 6 a distinct decline is visible in post-critical period, which is clearly related to the forced sale of the municipal property. It makes sense to subject the importance of this indicator to further investigation and analysis, since it can be one of many possible solutions addressing $3 \mathrm{E}$ principles in the public sector in the sense of the modified profitability of the entrusted assets of a municipality.

Table 7. Financial performance

\begin{tabular}{ccccccc}
\hline Municipality & 2007 & 2008 & 2009 & 2010 & 2011 & 2012 \\
\hline A & $3 \%$ & $-7 \%$ & $-4 \%$ & $7 \%$ & $-15 \%$ & $1 \%$ \\
B & $6 \%$ & $7 \%$ & $3 \%$ & $2 \%$ & $-11 \%$ & $2 \%$ \\
C & $-3 \%$ & $29 \%$ & $-54 \%$ & $-505 \%$ & $-24 \%$ & $4 \%$ \\
\hline
\end{tabular}

The indicator level of financial autonomy is a visibly common trend for all of the selected entities. There was a marked decline, with minimum values reached just before the occurrence of the negative financial situation in four of the six cases. Long-term trends for this indicator are somewhat visible, foreshadowing future developments, in the table 7.

Table 8. Level of financial autonomy

\begin{tabular}{ccccccc}
\hline Municipality & 2007 & 2008 & 2009 & 2010 & 2011 & 2012 \\
\hline A & 4.02 & 2.84 & 2.71 & 3.74 & 3.41 & 3.64 \\
B & 2.28 & 2.74 & 3.10 & 3.47 & 3.47 & 4.00 \\
C & 0.52 & 0.91 & 0.56 & -0.66 & -0.83 & -0.81 \\
\hline
\end{tabular}


In this case, a clear trend cannot be identified, only long-term poor performance. This raises the question of how to evaluate this indicator for public sector entities. There is a dichotomy problem of using such indicators (make profit or involve funds and finance)? Long-term poor performance may be due to several factors, such as inefficient management of municipal property or the specific structure and nature of the property. The analysis of municipal asset management certainly deserves an individual research approach. For example, rate of return is a very specific issue with various modifications and objectives. Each view on this issue should be individualized with respect to all objectives which each organization wants to achieve.

Table 9. Financial utilization of equity

\begin{tabular}{ccccccc}
\hline Municipality & 2007 & 2008 & 2009 & 2010 & 2011 & 2012 \\
\hline A & $-0.1 \%$ & $-0.2 \%$ & $-0.1 \%$ & $2.0 \%$ & $3.3 \%$ & $1.7 \%$ \\
B & $-0.5 \%$ & $0.0 \%$ & $0.2 \%$ & $0.5 \%$ & $0.3 \%$ & $1.3 \%$ \\
C & $0.1 \%$ & $0.2 \%$ & $0.5 \%$ & $-0.2 \%$ & $-2.4 \%$ & $-2.8 \%$ \\
\hline
\end{tabular}

There are doubts about use and explanatory power of such indicator in this specific area of municipalities as credit worthiness of the cash-flow. The point is, for example, higher spending on investments tend to be co-financed of subsidies, how is thus important to measure the ability of municipal own cash flow to cover the involved external sources (credits, loans).

Table 10. Credit worthiness of the cash-flow

\begin{tabular}{ccccccc}
\hline Municipality & 2007 & 2008 & 2009 & 2010 & 2011 & 2012 \\
\hline A & -470.51 & -142.93 & -531.85 & 13.61 & 8.84 & 15.90 \\
B & -87.04 & 1392.28 & 201.79 & 57.40 & 107.87 & 19.58 \\
C & 2924.51 & 497.63 & 358.98 & 920.86 & 49.75 & 44.43 \\
\hline
\end{tabular}

Based on table 11 can be stated there is no clear long-term trend of deteriorating budgetary situations in the budget balance in the pre-crisis period in the selected municipalities. The following table shows that most of observed municipalities had positive budget balances in the examined period. It would probably be more useful to see whether the expenditure structure of those municipalities changed within their approved budgets, and if so how. As the municipal budget is still the most well-known and used tool for managing municipal finances and is accepted by municipal residents as a control mechanism, its balance is probably not the only reliable indicator of municipal financial conditions.

Table 11. Annual budget balance

\begin{tabular}{ccccccc}
\hline Municipality & 2007 & 2008 & 2009 & 2010 & 2011 & 2012 \\
\hline A & + & + & + & + & - & + \\
B & - & + & + & + & + & + \\
C & + & + & - & + & - & + \\
\hline
\end{tabular}

The annual change of total assets is a simple indicator that proves in this case that Czech municipalities were affected by the occurrence of negative financial situations. This is probably one of the main disadvantages resulting from the occurrence of financially negative situations. 
Table 12. Annual percentage changes of total assets

\begin{tabular}{ccccccc}
\hline Municipality & 2007 & 2008 & 2009 & 2010 & 2011 & 2012 \\
\hline A & $1 \%$ & $1 \%$ & $-3 \%$ & $-1 \%$ & $-13 \%$ & $-1 \%$ \\
B & $12 \%$ & $1 \%$ & $0 \%$ & $-1 \%$ & $-11 \%$ & $-1 \%$ \\
C & $0 \%$ & $-7 \%$ & $-39 \%$ & $-25 \%$ & $-51 \%$ & $13 \%$ \\
\hline
\end{tabular}

Table 13. Annual percentage changes of short-term liabilities

\begin{tabular}{ccccccc}
\hline Municipality & 2007 & 2008 & 2009 & 2010 & 2011 & 2012 \\
\hline A & $-18 \%$ & $256 \%$ & $11 \%$ & $-45 \%$ & $-57 \%$ & $31 \%$ \\
B & $196 \%$ & $159 \%$ & $5 \%$ & $-79 \%$ & $10 \%$ & $3 \%$ \\
C & $2 \%$ & $-26 \%$ & $-26 \%$ & $-8 \%$ & $-25 \%$ & $-9 \%$ \\
\hline
\end{tabular}

Based on table 13 a significant link in the development of the structure of total liabilities was not identified, but in most cases there was an increase in short-term liabilities in the period preceding the negative financial situation, although they differed in their growth dynamics. Some of them made significant jumps in the preliminary phase. In all cases, each municipality encountered a capital-intensive action, such as housing, sewerage, or a wastewater treatment plant. This raises questions of how to finance similar actions, if they are the cause of the negative financial situation. It could be very advantageous to study this variable in context with other financial variables such as liquidity.

It does not seem like a trend but a valuable point for further research could be the relationship between changes in short-term liabilities and the acid-test ratio or different versions of liquidity ratios. Observing all cases in this study, it is clear that reaching high percentage changes of short-term liabilities associated with subsequent lows of the acid-test ratio could signal problems for the financial condition of the municipality, as is seen in all cases within the observed time period.

\section{Discussion}

Partial goal of this paper was to find existing research studies on this topic and self-conduct empirical research to see whether there are common features or characteristics associated with municipal bankruptcy or bad financial situation of municipalities across different countries. According to a certain level of uniqueness and inner heterogeneity of bankruptcy issue not everything is relevant and thus comparable. Therefore this part of research is very difficult to carry out and it would be maybe better as an individual research issue. One of main arguments pointing out the inner difference within this issue is the level and extent of duties and activities performed by local governments internationally (case by case). For example one of the major factors in growing numbers of local governments bankruptcies is the amount of underfunded pension and other post-employment benefits accrued by local governments (Fischer et al., 2015). But especially pension obligations are not the matter of local governments everywhere (especially not in the cases of the Czech Republic). Therefore we need to seek for comparable aspects which can strengthen our knowledge and experience with bankruptcy and thus improve the system (public financial management, state regulation, public policy, organizational performance etc.) From the perspective of this paper it could be interesting to point out characteristics assigned to bad financial situation of a municipalitiy due ACIR (1973) where:

- An Operating Fund Revenue-Expenditure Imbalance in Which Current Expenditures Significantly Exceeded Current Revenues in One Fiscal Period;

- A Consistent Pattern of Current Expenditures Exceeding Current Revenues by Small Amounts for Several Years;

- An Excess of Current Operating Liabilities over Current Assets (A Fund Deficit);

- Short-Term Operating Loans Outstanding at the Conclusion of A Fiscal Year (Or In Some Instances the Borrowing of Cash from Restricted Funds Or an Increase in Unpaid Bills in Lieu of Short-Term Operating Loans);

- A High and Rising Rate of Property Tax Delinquency;

- A Sudden Substantial Decrease in Assessed Values for Unexpected Reasons. 
Many Defaulting Municipalities then Intensified the Impact of the Environmental Factors by:

- Being Slow to Reduce Controllable Expenditures;

- Using Short-Term Debt to Finance Large Operating Deficits;

- Continuing to Eschew Sound Budgeting Techniques.

Ritonga et al. (2012) found that local governments in Indonesia perceive the dimension of long-term solvency and short-term solvency as the two most important dimensions. They added that service-level solvency is considered as the least important of elements of the financial condition and concluded that local governments tend to have short-term horizons rather than long-term horizons in managing local government finance. Manes Rossi et al. (2012) found and introduced one of new ways (model) to prevent municipal financial distress based on following indicators: consistency of financial result; quality of financial results; consistency of credits by operating revenues; current financial equilibrium; rigidity of personnel expenses; debts limit; theoretical time for paying off debts; anticipation by treasury; debts by operating expenses. Brusca and Manes Rossi (2015) point out based on their sample that meanwhile in Spain indicators such as capital expenditure per capita and the percentage of personal expenditure over operative revenues influence the financial stress of municipalities, in Italy the influence is not very strong and more important from this perspective are indicators such as fiscal revenues over GDP, fiscal pressure and the operative transfers and grants.

\section{Conclusions}

Despite its limited scope, this pilot research presented interesting results which, although they cannot be generalized due to the small sample, but can be used for further research. The issue of municipal bankruptcy is still not sufficiently explored in terms of public financial management and this particular issue suffers by lack of empirical findings, available relevant information and limited subjects for research sample. One reason may be the lack of relevant legislation for municipal bankruptcy and the continuing discussion of this issue without a significant shift to the practical application of a solution. In terms of comparison with similar conclusions, several problematic aspects are seen, one of which is the delayed implementation of accounting reform in the Czech public sector. For this reason, there is lower consistency between the functioning of the municipal budget and municipal property within the observed time period. The absence of legislated bankruptcy status was another problem in determining the appropriate subjects for this pilot research. Forced distraint of municipal property, which is an involuntary act to which an economic entity is subjected if it is unable to meet its liabilities, and which is among the conditions qualifying economic entities as being in a negative financial situation (such as bankruptcy), was chosen as the key criterion for sample selection in the Czech Republic. Despite some shortcomings, the research draws some valuable conclusions for further reflection and research. Brief qualitative analysis of examined cases showed that one of the common reasons of bankruptcy occurrence seems to be credits associated with municipal entrepreneurship or development. But to identify properly the relevant conditions and settings for the prediction of negative financial situation further relevant research is required.

Future research should go wider - using other indicators from the perspective of financial analytics — and deeper -looking for more interconnections between the variables and for more concrete processes which led to the negative financial situation. Kloha et al. (2005) point out the aspect—number of used variables taken into account according in the assessment. Different models and approaches use different number, structure and dimensions when constructing complex tool which is supposed to assess or even predict municipal bankruptcy. Therefore the issue of relevant indicators is highly desirable to solve in each specific case (data). This research should continuously tackle and answer the questions considering the suitable amount and structure of relevant indicators. Brusca and Manes Rossi (2015) show the importance of national perspective and associated differences in this particular issue (relevancy of indicators) on the case of Italy and Spain when they point out that there are different indicators influencing the financial stress of municipalities in each country. This argument as some other support the view that any financial analysis of municipal bankruptcy or stress should take into account national specifics and thus its structure usually differs.

All of the observed municipalities in this study survived the negative financial situation even without the traditional bankruptcy modus which provides benefits such as protection from creditors. Despite the negative situation, these municipalities are still functioning and providing basic services for their residents. This is meaningful from two research perspectives. First, what does it cost, with or without bankruptcy modus, to survive? Second, if the municipalities survived without bankruptcy modus, is it necessary to develop and implement legislation like other countries? The second question is of particular interest because of ongoing discussions that municipal bankruptcy could potentially lead to a moral hazard. This subject raises more and more questions to be addressed and solved as the local government level is becoming increasingly important in 
public administration due to processes of further decentralization and autonomy. Another reason is growing risks and a more turbulent recent environment. Thus it is highly desirable to strengthen the predictive ability of municipal financial management, used concepts and tools to keep municipalities from bankruptcy. Therefore the relevant research leading to improve or even invent the predictive power of municipal financial management is highly desirable (e.g. Carmeli 2003; Hendrick 2004; Kloha et al. 2005; Elliehausen \& Lawrence 2013; Justice \& Scorsone 2013; Skogsvik, K., \& Skogsvik 2013).

\section{Limitations on the Research Design and Material}

This particular research is strongly aware of its limitations. First limitation is worldwide and it is associated with the specificity of this particular issue (municipal bankruptcy). Local governments wolrdvide are based on different fundamentals and exist in various condition. The second limitation is small sample of municipalities which were identified as a suitable to be selected for the purpose of this specific research according to the similar timeframe and conditions. The research sample is small mainly from two reasons which are from our point of view reasonable in this pilot case. First is the will to compare cases which are similar from the perspective of time period (when the negative financial condition occurred) and of financial condition view (financial state equal or similar to the bankruptcy). Second reason is associated with the total number of municipalities (since 1993) which were in such bad financial condition and therefore they had to rapidly reduce its services or were forced to immediate sale of municipal assets. In spite of the fact that Czech municipal sector is belonging to those which are too fragmented, the total number of such cases observed and recorded within determined time period is very small. The last but not least reason is more complicated identification (purity and clarity) of suitable bankruptcy cases at all according to missing relevant legislation. The outcomes achieved thanks to this preliminary research are of pilot nature and bring first insights into this particular issue in this specific case.

\section{Acknowledgement}

This paper was prepared within the framework of the project of specific research at Masaryk University.

\section{References}

Advisory Commision on Intergovernmental Relations. (1973). A Commission Report/City Financial Emergencies: The lntergovernmental Dimension ACIR. Washington, D.C.

Advisory Commision on Intergovernmental Relations. (1985). A Commission Report Bankruptcies, Defaults, And Other Local Government Financial Emergencies ACIR. Washington, D.C.

Advisory Commision on Intergovernmental Relations. (1985). Bankruptcies, Defaults, And Other Local Government Financial Emergencies. A Commission Report. Washington.

Act No. 128/2000 Sb., o obcích (obecní zrrízení). (2013). Municipal Act for Czech Republic. Retrieved from http://portal.gov.cz/app/zakony/zakon.jsp?page $=0 \& n r=128 \sim 2 F 2000 \& r p p=15 \#$ eznam

ARIS. (2013). Czech Republic Ministry of Finance database. Retrieved from http://wwwinfo.mfcr.cz/aris/

Bakoš, E., Soukopová, J., \& Šelešovský, J. (2015). The Historical Roots of Local Self-Government in Czech and Slovak Republics. Lex Localis, 13(1). http://dx.doi.org/10.4335/13.1.1-19(2015)

Benito, B., Guillamón, M. D., \& Bastida, F. (2015). Debt limits non-fulfillment in Spanish municipalities. Fiscal Studies, 36(1), 75-98. http://dx.doi.org/10.1111/j.1475-5890.2015.12046.x

Benito, B., \& Bastida, F. J. (2004). The determinants of the municipal debt policy in Spain. Journal of Public Budgeting, Accounting \& Financial Management, 16(4), 525-558.

Bolívar, M. P. R., Galera, A. N., Muñoz, L. A., \& Subirés, M. D. L. (2014). Factors influencing local government financial sustainability: An empirical study. Lex Localis, 12(1).

Brown, K. W. (1993). The 10-Point Test of Financial Condition: Toward an Easy-to-Use Assessment Tool for Smaller Cities.

Brusca, I., \& Manes Rossi, F. (2015). Drivers for the financial condition of Local Government: A comparative study between Italy and Spain. Lex Localis, 13(2), 161-184. http://dx.doi.org/10.4335/13.2.161-184(2015)

Carmeli, A. (2003). Introduction: Fiscal and Financial Crises of Local Governments. Internationaal Journal of Public Administration, 26(13), 1423-1430. http://dx.doi.org/10.1081/PAD-120024404

Civitillo, R. (2012). Financial difficulties of Italian local authorities: A financial critical elements analysis to identify prediction and diagnosis models. Athens: ATINER'S Conference Paper Series, No: MDT2012-0014. 
Coe, C. K. (2008). Preventing local government fiscal crises: Emerging best practices. Public Administration Review, 68(4), 759-767. http://dx.doi.org/10.1111/j.1540-6210.2008.00913.x

Elliehausen, G., \& Lawrence, E. C. (2013). County-level bankruptcy beta and its impact on the supply of revolving credit. Investment Management and Financial Innovations, 10(1).

Evans, J. H., \& Patton, J. M. (1987). Signaling and Monitoring in Public-Sector Accounting. Journal of Accounting Research, 25, 130-158. http://dx.doi.org/10.2307/2491083

Fischer, M., Marsh, T., \& Bunn, E. (2015). Fiscal Health Analysis Of Texas And Its Municipalities. Journal of Business \& Economics Research, 13(2).

Fitzpatrick, P. J. (1932). A Comparison of the Ratios of Successful Industrial Enterprises with Those of Failed Companies. The Accountants Publishing Company.

Fudge, M. (2014). The Varied and Diverse Predictors of Local Government Bankruptcy. PA Times. Retrived from http://patimes.org/varied-diverse-predictors-local-government-bankruptcy/

Gras, E., Hernandez, J., \& Palacios, M. (2014). An Explanation of Local Government Debt in Spain Based on Internal Control System. Lex Localis, 12(4).

Groves, S. M., Godsey, W. M., \& Shulman, M. A. (1981). Financial Indicators for Local Government. Public Budgeting \& Finance, 1(2), 5-19. http://dx.doi.org/10.1111/1540-5850.00511

Hendrick, R. (2004). Assessing and Measuring the Fiscal Health of Local Governments: Focus on Chicago $\begin{array}{llll}\text { Suburban } \quad \text { Municipalities. Urban Affairs } & \text { Review, }\end{array}$ http://dx.doi.org/10.1177/1078087404268076

Honadle, B. W., \& Lloyd, J. M. (1998). Analyzing Rural Local Governments' Financial Condition: An Exploratory Application of Three Tools. Public Budgeting \& Finance, 18(2), 69-86. http://dx.doi.org/10.1046/j.0275-1100.1998.01135.x

Horváthová, L., Horváth, J., Gazda, V., \& Kubák, M. (2012). Fiscal Decentralization and Public debt in the European Union. Lex Localis, 10(3).

Hossari, G. (2007). Modelling Corporate Collapse: Definitional Issues of the Collapse Event. Journal of applied management accounting research, 3(2), 75-84.

Hrůza, F. (2014). The effect of the financial crisis on Czech municipal financial management: Can a future crisis be prevented? Problems and Perspectives in Management, 12(1), 143-151.

Hrůza, F. (2013). Liquidity Management as a Space for Public Sector Innovation: How the Public Sector Approach to This Issue Has Developed through the Time until Now? In Proceedings of 2013 international conference on public administration (9th) (pp. 413-421). Chengdu: University of Electronic Science and Technology of China Press (UESTC Press),

Jones, S., \& Walker, R. (2007). Explanators of Local Government Distress. Abacus, 43(3), 396-418. http://dx.doi.org/10.1111/j.1467-6281.2007.00238.x

Justice, J. B., \& Scorsone, E. A. (2013). Measuring and predicting local government fiscal stress: Theory and Practice. In H. Levine, J. B. Justice, \& E. A. Scorsone (Eds.), Handbook of local government fiscal health. Burlington, Mass.: Jones \& Bartlett.

Kloha, P., Weissert, C., S., \& Kleine, R. (2005). Developing and Testing a Composite Model to Predict Local $\begin{array}{llll}\text { Fiscal Distress. Public } \quad \text { Administration } & \text { Review, 65(3), }\end{array}$ http://dx.doi.org/10.1111/j.1540-6210.2005.00456.x

Maher, C. S., \& Nollenberger, K. (2009). Revisiting Kenneth Brown's "10-Point Test." Government Finance Review, 25(5), 61-66.

Manes Rossi, F., Zito, M., \& Costanzo, A. (2012). How to prevent distress in local government: A new model applied in Italy. Advanced Research in Scientific Areas 2012. Retrieved from http://arsa-conf.com/archive/?vid=1\&aid=3\&kid=60101-106\&q=f1

Mateos-Ronco, A., \& Mas, A., L. (2011). Developing a business failure prediction model for cooperatives: Results of an empirical study in Spain. African Journal of Business Management, 5(26), 10565-10576. http://dx.doi.org/10.5897/ajbm11.1415

Mcconnell, M. W., \& Picker, R. C. (1993). When Cities Go Broke: A Conceptual Introduction to Municipal Bankruptcy. The University of Chicago Law Review, 60(2), 425-495. http://dx.doi.org/10.2307/1600077 
Merwin, Ch. L. (1940). Financial Characteristics of American Manufacturing Corporations. Washington. U.S. Government Printing Office, 15, 442.

Ministry of Finance Czech Republic. (2013). System of informative and monitoring indicators. Retrieved from $\mathrm{http} / / / \mathrm{www} . \mathrm{mfcr} . \mathrm{cz} / \mathrm{cps} / \mathrm{rde} / \mathrm{xchg} / \mathrm{mfcr} / \mathrm{xsl} / \mathrm{vf}$ _monitoring_hospodareni_obci.html

Moderní Obec. (2013). Jak řešit možné úpadky obcí? Diskuse o tom teprve začiná. Retrieved from http://moderniobec.ihned.cz/c1-58230500-jak-resit-mozne-upadky-obci-diskuse-o-tom-teprve-zacina

Ngwenya, S. (2010). Evaluating financial conditions of local governments in South Africa-A case of metropolitan municipalities in Gauteng. International Research Symposium in Service Management.

Padovani, E., \& Scorsone, E. (2014). Through The Complexity of Bankruptcy in Local Governments. Public Finance and Management, 14(1).

Ritonga, I. T., Clark, C., \& Wickremasinghe, G. (2012). Assessing financial condition of local government in Indonesia: an exploration. Public and Municipal Finance, 1(2).

Rivenbark, W. C., Roenigk, D. J., \& Allison, G. S. (2009). Communicating Financial Condition to Elected Officials in Local Government. Popular Government, Fall, 4-13.

Rivenbark, W. C., Roenigk, D. J., \& Allison, G. S. (2010). Conceptualizing Financial Condition in Local Government. Journal of Public Budgeting, Accounting \& Financial Management, 22, 149-177.

Skogsvik, K., \& Skogsvik, S. (2013). On the choice based sample bias in probabilistic bankruptcy prediction. Investment Management and Financial Innovations, 10(1).

Smith, R. F., \& Winakor, A. H. (1930). A Test Analysis of Unsuccessful Industrial Companies. Bulletin No. 31, University of Illinois, Bureau of Business Research.

UFIS. (2013). Czech Republic Ministry of Finance database. Retrieved from http://wwwinfo.mfcr.cz/ufis/

United States Courts (US Courts). (2013). Retrieved from http://www.uscourts.gov/FederalCourts/Bankruptcy/BankruptcyBasics/Chapter9.aspx

Ústava České republiky. (2013). The Constitution of Czech Republic. Retrieved from http://www.psp.cz/docs/laws/constitution.html

Wang, X., Dennis, L., \& Tu, Y. S. J. (2007). Measuring Financial Condition: A Study of US States. Public Budgeting \& Finance, 27(2), 1-21. http://dx.doi.org/10.1111/j.1540-5850.2007.00872.x

\section{Copyrights}

Copyright for this article is retained by the author(s), with first publication rights granted to the journal.

This is an open-access article distributed under the terms and conditions of the Creative Commons Attribution license (http://creativecommons.org/licenses/by/3.0/). 